TITLE:

\title{
MARINE INSECTS OF THE TOKARA ISLANDS -VIII. FAMILY STAPHYLINIDAE (COLEOPTERA)-
}

AUTHOR(S):

Sawada, Kohei

\section{CITATION:}

Sawada, Kohei. MARINE INSECTS OF THE TOKARA ISLANDS -VIII. FAMILY STAPHYLINIDAE (COLEOPTERA)-. PUBLICATIONS OF THE SETO MARINE BIOLOGICAL LABORATORY 1955, 5(1): $81-87$

ISSUE DATE:

1955-12-20

URL:

http://hdl.handle.net/2433/174533

RIGHT: 


\title{
MARINE INSECTS OF THE TOKARA ISLANDS \\ VIII. FAMILY STAPHYLINIDAE (COLEOPTERA) $)^{1}$ )
}

\author{
KOHEI SAWADA \\ Biological Laboratory, Saikyô University, Kyoto
}

With Plates $X I V$ and $X V$

This paper is based on the material obtained through the scientific expedition of Tokara Islands, off the south of the island of Kyushu, in 1953, and includes descriptions of two new genera and six new species, all belonging to the same group of the subfamily Aleocharinae.

The type specimens designated in the present paper are preserved in the collection of the Osaka Municipal Museum of Natural History, partially in our laboratory.

Before going further I express my hearty thanks to Professor Dr. T. EsAKI, Mr. M. Hayashi, Mr. M. Iga, Professor S. Miyamoto, Professor T. Nakane, Mr. K. SAKAGUCHI and Mr. S. UÉNo for their constant supporting and guidance. Also I must acknowledge the cooperation of the Museum.

\section{Genoplectes, gen. nov.}

Head large, sides subparallel; labrum transverse, arcuate and setigerous at the front margin, its lateral sides slightly divergent basally; labial palpi 3-jointed, robust, articulation between the 1st and 2 nd joint obscure, with the 1st joint short, 2nd more than twice as long as 1st, scarcely constricted behind, 3rd narrower, about a half as long as 2nd; maxillae chitinous, with outer lobes broad, slightly curved inwards, distinctly ciliate at the truncate apex, not converging towards the tip, inner lobes voluminous proximally, scarcely shorter than the outer, loosely pointed and moderately incurved distally, 5 or 6 irregular setae on the inner margin; mentum transverse, strongly and deeply sinuate on the front margin, distinctly dilated basally at sides; mandibles robust, gently pointed at the apex, the right one with an acute short tooth in the middle of the inner margin, the left simple; maxillary palpi in ordinary form, the 1st joint small, 2nd large, dilated at the middle, 3rd slightly longer than 2nd, distinctly dilated distally, 4th only one-fourth as long as $3 \mathrm{rd}$, subtruncate at apex; eyes small; genae obliquely grooved, with two short plicae; gular plate broad, parallel

1) Scientific Survey of the Tokara Islands, Report No. 22.

Publ. Seto Mar. Biol. Lab., V (1), 1955. (Article 5) 
but somewhat narrowed at the middle; antennae slightly dilated distally, with the 1st joint robust and constricted behind, 2nd shorter than 1st, 3rd longer than 4th, narrower than the preceding, the rest of moniliform, 11th longer than 10th, not pointed.

Pronotum subcordate, distinctly constricted behind, apparently declivous laterally; scutellum very large, convex above.

Elytra strongly abbreviated in length, apparently convex at the middle, the suture slightly but apparently dehiscent in full length.

Abdomen distinctly dilated distally, thick; tarsal formula 4-4-4, tarsi with the first 3 joints generally short and subequal in length, 4 th subequal to the basal rest but the hind one distinctly longer; prosternum broad, shortly pointed behind, meso- and metasternum very narrow; fore coxal cavities broadly opened behind, middle coxae and hind coxae strongly approximate to each other.

Genotype: Genoplectes uenoi, sp. nov.

This new genus resembles in habitat and general appearance Diglotta CHAMPION, 1887 and Liparocephalus MäKLIN, 1853. But in some important characters it shows as belonging to the tribe Hygronomini. It may be near the genus Bamona SHARP, 1883.

\section{Genoplectes uenoi, sp. nov.}

Male. $2.2 \mathrm{~mm}$. Body elongate, convex above, robust, distinctly pubescent throughout, lustrous; piceous, the distal half of the abdomen blackish, head somewhat infuscate, legs paler.

Head large, parallel but slightly dilated distally, moderately longer than broad, finely and densely punctured, mandibles relatively large and produced distally, eyes small, rather rudimentary, genae well-developed, moderately expanded laterally; antennae with the elongate 1st joint slightly bent inwards, 2nd subtruncate at the apex, 3rd apparently constricted behind, 4th as broad as long, 10th about as long as broad, 11th slightly longer than 10th, gently pointed; neck broad and short, hidden by the pronotum; pronotum seemingly longer than broad, convex, minutely shagreened above, inflexed laterally, prothoracic epipleura scarcely visible from side, the greatest width at the anterior one-third, and then, abruptly constricted behind, with sides gently sinuate before the hind angles; scutellum very large, convex, triangularly pointed behind, pubescent; elytra very short, a half as long as pronotum, suture dehiscent in full length, humeri not distinct, rather distinctly, coarsely punctured; abdomen voluminous, apparently divergent distally, three visible tergites deeply defined and impressed at the base, pygidium almost impunctate but densely punctured proximally; legs moderately long, with the robust femora, and front tibiae densely spinose, claws long, broadly separated; female unknown.

Holotype: One male, Nakanoshima (Yoriki), 4-VI-1953. Collected by Mr. S. UÉno. 
Halesthenus, gen. nov.

Body linear, rather depressed above; labrum produced distally, rounded with an additional membrane apically, mandibles short, robust, obtusely pointed, the right one with a small tooth on the basal part of the inner margin, the left simple, maxillae with the outer lobes shorter than the inner lobes, fully thin and corneous, nearly straight, slightly incurved at the extreme distal part, the inner lobes elongate, only weakly incurved at the apex, more chitinous than that of the outer one, on the distal half bearing 5 or 6 minute dentations, and 5 additional long hairs at the proximal rest, mentum transverse, broadly and deeply excised at the front margin, ligula short, membraneous, entire, subtruncate at the front margin, maxillary palpus 4 -jointed, the 1st joint small, triangular, 2nd subequal to $3 \mathrm{rd}$, moderately incrassate at the middle, 3 rd also incrassate anteriorly, the last one small, labial palpus bristle-like, :2-jointed, but the articulation between 1st and 2nd joint indistinct, the 1st joint elongate, twice as long as 2nd, with a small, appendage at the tip of 2nd, infra-orbital carina vanishing; prothoracic epipleura more or less visible from the side, prosternum obtusely angulate posteriorly, mesosternal process elongate, more or less pointed, front coxae moderately separated, middle one fully approaching basally; tarsal formula 4-4-5, fore and middle tarsi with the first 3 joints short and subequal in length, the last one longer than the predecessor, hind tarsi with the 1st joint as long as 5th, 2nd to 4 th short and subequal in length; antennae elongate, each joint not transverse, not incrassate distally, with the 1st joint robust, 2 nd subequal to 1st, 11th usually longer than the preceding, lightly pointed.

Genotype: Halesthenus minutus, sp. nov.

The characteristics of the genus described here are similar to those of Bryobiota CASEY, 1893, in general, but the genus is different from it mainly by the form of maxillae, especially elongate labial palpus.

Key to the species

1. Body small (1.5 $\mathrm{mm})$, eyes rudimentary. minutus, sp. nov. Body large (more than $2.2 \mathrm{~mm}$ ), eyes normal. 2.

2. 3rd joint of maxillary palpus not cylindrical and broadly hollowed at the middle of outer surface, 4 th joint broad and very short. tsutsuii, sp. nov. 3rd joint more or less cylindrical and not hollowed, 4th joint normally formed.

3. Body weakly chitinized, pale yellowish in colour, eyes of moderate size.... serpentis, sp. nov. Body distinctly chitinized, brownish to blackish in colour, eyes large. nakanei, sp. nov.

\section{Halesthenus minutus, sp. nov.}

Male. $1.6 \mathrm{~mm}$. Body linear, depressed above ; dull in lustre; pale yellowish brown, legs and antennae somewhat paler.

Head orbicular, as broad as pronotum, slightly produced distally, gently convex above, punctures obscure, rather alutaceous, mandibles relatively large, labial palpi sur- 
passing the top of mandibles, maxillary palpi rather large, eyes rudimentary, gular plate broad, moderately widened behind; antennae slender, apparently attaining to the base of elytra, the 1st joint large, slightly thickened at the middle, 2nd slightly shorter than the preceding one, but more cylindrical, 3rd of egg-cup-shaped, distinctly constricted proximally, 4 th to 10 th gradually increasing in length, 11th subequal to 10th and 9th conjointly, gently pointed; pronotum quadrate, nearly deplanate on disc, narrowly inflexed laterally, the front angles not rounded, with a short fixed seta, sides almost straight, only invisibly sinuate before the posterior angles which are loosely angulate; elytra subequal to the pronotum in length and breadth, plain; without distinct punctures; apterous; abdomen subparallel, feebly divergent posteriorly, slightly broader than the elytra, finely, densely pubescent and rather finely punctured, legs slender, claws minute, simple.

Holo-, allo- and paratypes: One male and three females. Nakanoshima (Yoriki), 4-VI-1953. Collected by Mr. S. UÉno.

\section{Halesthenus tsutsuii, sp. nov.}

Male. $2.7 \mathrm{~mm}$. Piceous, distal half of the abdomen infuscate, visible 4th segment especially blackish, finely and distinctly pubescent throughout.

Head rather depressed above, alutaceous, broader than that of minutus comparatively, eyes small, not prominent with coarse facets; antennae of minutus, but 4th joint not so strongly constricted basally and 11th more slender and more acutely pointed; maxillary palpus with the 1st joint minute, 2nd elongate, not cylindrical, flexed and curved inwards, 3rd dilated distally, with obliquely truncate apex, and apical margin finely pubescent, shallowly but broadly concave on the external surface of the widened middle part, 4th very short and broad, abruptly truncate at the apex; pronotum as in minutus, but seemingly broader and more distinctly convergent backwards, disc with a slight excavation basally, the hind margin, including the basal half of sides, bordered with a narrowly reflected edge, alutaceous; elytra plain, sculptured as in pronotum; abdomen finely and densely punctured; legs rather slender.

Holotype and allotype: Takarajima, 29-V-1953. Collected by Professor S. Miуамото.

In General appearance this species is notably allied to $H$. minutus, but easily separable from it by the much larger size of the body and the otherwise formed maxillary palpus, etc.

\section{Halesthenus serpentis, sp. nov.}

Female. $2.6 \mathrm{~m}$. Of the facies of $H$. tsutsuii greatly, but the body narrower and the pronotum more quadrate. Antennae with the last joint shorter and broader than that of $t$ sutsuii, the maxillary palpus of the ordinary form as in minutus, the 3rd joint 
not hollowed internally, similarly punctured as the preceding, but finer and denser, and abdomen impunctate, rather reticulate or leather-like.

Holotype and two paratypes: Nakanoshima (Amadomari), 9-VI-1953. Collected by Mr. S. UÉNO.

\section{Halesthenus nakanei, sp. nov.}

Male. $2.2 \mathrm{~mm}$. Body elongate, subparallel-sided, well-chitinized; weakly polished; head and pronotum brown, elytra becoming yellow towards the extremity, abdomen fuscous, but the extreme distal region paler, head, pronotum and elytra finely alutaceous.

Head orbicular, seemingly transverse, gently convex, finely pubescent above, eyes well-developed, larger than that of tsutsuii and serpentis, prominent with rough facets, mandibles robust, produced distally, the right one with a small tooth basally, labial palpi elongate, evidently produced beyond the top of the mandibles as in other relatives, infraorbital plica vanishing, maxillary palpus with the 2 nd joint moderately widened distally, without flexion and curve, broadly hollowed at the inner surface but not so abruptly as in tsutsuii, antennae rather short, slender, scarcely thickened towards the apex, the scape slightly longer than the 2nd, 3rd longer than 4th, 10th feebly transverse, 11th shorter than 10th and 9th combined. Pronotum apparently transverse (14:11), moderately convex, acutely, strongly inflexed laterally, with the greatest width at the apical one-third, being gently narrowed anteriorly and the basal rest abruptly convergent backwards, the front angles indistinct, the hind ones rather distinct because of the feeble sinuation set just before them, a fine sulcus running along the front margin at a short distance. Elytra apparently longer (15:11), and slightly broader, than the pronotum. Abdomen rather coriaceous, moderately impressed at the base of each tergite, furnished with long yellowish hairs laterally. Mesosternal process sharply pointed behind. Tarsi of the likeness of tsutsuii and serpentis.

Holotype: Takarajima, 29-V-1953. Collected by Mr. S. UÉNo.

There are some notable characteristics in the new species as follows:

1. The integument of the body being chitinous conspicuously,

2. strongly infuscate coloration in general, and

3 . an abrupt constriction of the pronotum.

Thus easily distinguishable from the preceding by the visible characters abovementioned.

\section{Ischnopoda (Stethusa) miyamotoi, sp. nov.}

Female. $2.2 \mathrm{~mm}$. Body testaceous, head, meso- and metasternum, and abdomen more or less infuscate; polished; distinctly pubescent throughout.

Head orbicular, comparatively small, seemingly narrower than pronotum, densely and distinctly punctured, vertex slightly concave longitudinally, hind angles narrowly 
rounded, hind margin rather abrupt, genae not margined, eyes small, feebly prominent, labrum distinct, subquadrately produced distally, with front angles rounded, and nearly straight at the front magin, the right mandible with a tooth just behind middle of the inner margin; maxillary palpi ordinarily formed, its last subulate joint subtruncate at apex, only one-third as long as 3rd; antennae slender, scarcely divergent distally, the scape feebly incrassate to the extremity, sides slightly outcurved, 2nd joint shorter and narrower than 1st, 3rd again shorter than 2nd, abruptly constricted basally, 4th not transverse, 6th to 10 th gradually increasing in breadth, 11th conic, shorter than 10th and 9th conjointly, all of joints armed with some blackish hairs. Pronotum subcordiform, scarcely transverse, punctured more finely and densely than the head, margin apparently inflexed below with a rounded edge, sides nearly straight with a weak sinuation behind middle, front margin apparently oblique on both sides, disc moderately sulcate longitudinally, scutellum unnoticed. Elytra punctured as in head, but more sparsely and coarsely, slightly broader and apparently longer than pronotum, rather depressed above, humeri slightly prominent. Abdomen highly polished, thicker, feebly divergent distally, first three visible tergites deeply depressed basally, apparently and coarsely punctured. Legs slender, with elongate femora, hind tarsi with the 1st joint subequal to 2nd and 3rd conjointly, prosternum broadly occupying, shortly angulate behind, mesosternal process rather prolonged, and acutely pointed.

Holotype: Nakanoshima (Amadomari), 6-VI-1953. Collected by Mr. S. Uénó.

This elegant species somewhat resembles in facies I. transfuga SHARP, 1874, but is radically separated from it by the articulation of antennae, coloration of the body, and by other points.

\section{LITERATURE CITED}

Blackwelder, R. E. 1952. The generic names of the family Staphylinidae, with an essay on genotype. Bull. U.S. Nat. Mus. 200, pp. 1-483.

Cameron, M. 1920. New species of Staphylinidae from Singapore. Part III. Trans. Ent. Soc. London, pp. 212-284.

1939. The fauna of British India, including Ceylon and Burma, Staphylinidae. vol. 4 , pt. 1 , pp. 1-400. London.

CASEY, T. L. 1910. Memoire on the Coleoptera. 1. pp. 1-205. Lancaster.

Chamberlin, J. C. et Feriss, G. F. 1929. On Liparocephalus and allied genera. Pan-Pacific Ent., vol. 5, No. 2, pp. 137-143.

Cruardet, F. (1937). Tableau du determination des Atheta de France. Rev. franç. d'Ent., Tome 4.

FENyES, A. 1921. Coleoptera: Fam. Staphylinidae, Subfam. Aleocharinae, Genera Insectorum, Fasc. 173, pp. 1-453.

Portevin, G. 1929. Histoire naturelle des Coléoptères de France. I. Staphylinoidea. pp. 1-460. Paris.

Reitter, E. 1909. Fauna Germanica. Bd. 2, pp. 1-200. Stuttgart.

SAKAguti, K. 1944. A new intertidal rove-beetle from the Pacific coast of Japan. Trans. Kansai Ent. Soc., vol. 14, pt. 1, pp. 18-21.

SharP, D. 1874. The Staphylinidae of Japan. Trans. Ent. Soc. London, pp. 1-101. 


\section{EXPLANATION OF PLATES XIV-XV}

Fig. 1. Genoplectes uenoi, sp. nov.

Fig. 2.

Fig. 3. Halesthenus minutus, sp. nov.

Fig. 4.

Fig. 5.

Fig. 6.

Fig. 7.

Fig. 8. Halesthenus tsutsuii, sp. nov.

Fig. 9. Halesthenus nakanei, sp. nov.

Fig. 10. Halesthenus tsutsuii, sp. nov.
Maxilla and labium.

$\times 145$

Labrum.

$\times 278$

Clypeus and labrum.

$\times 282$

Antenna. Pubescence not shown. $\times 145$

Maxilla.

$\times 289$

Labium.

$\times 298$

3rd and 4th joint of maxillary palpus. $\times 380$

$\times \mathbf{1 8 0}$

$\times 175$

Aedeagus. Ventral view.

$\times 142$ 
Publ. Seto Mar. Biol. Lab., V, 1 (1955)
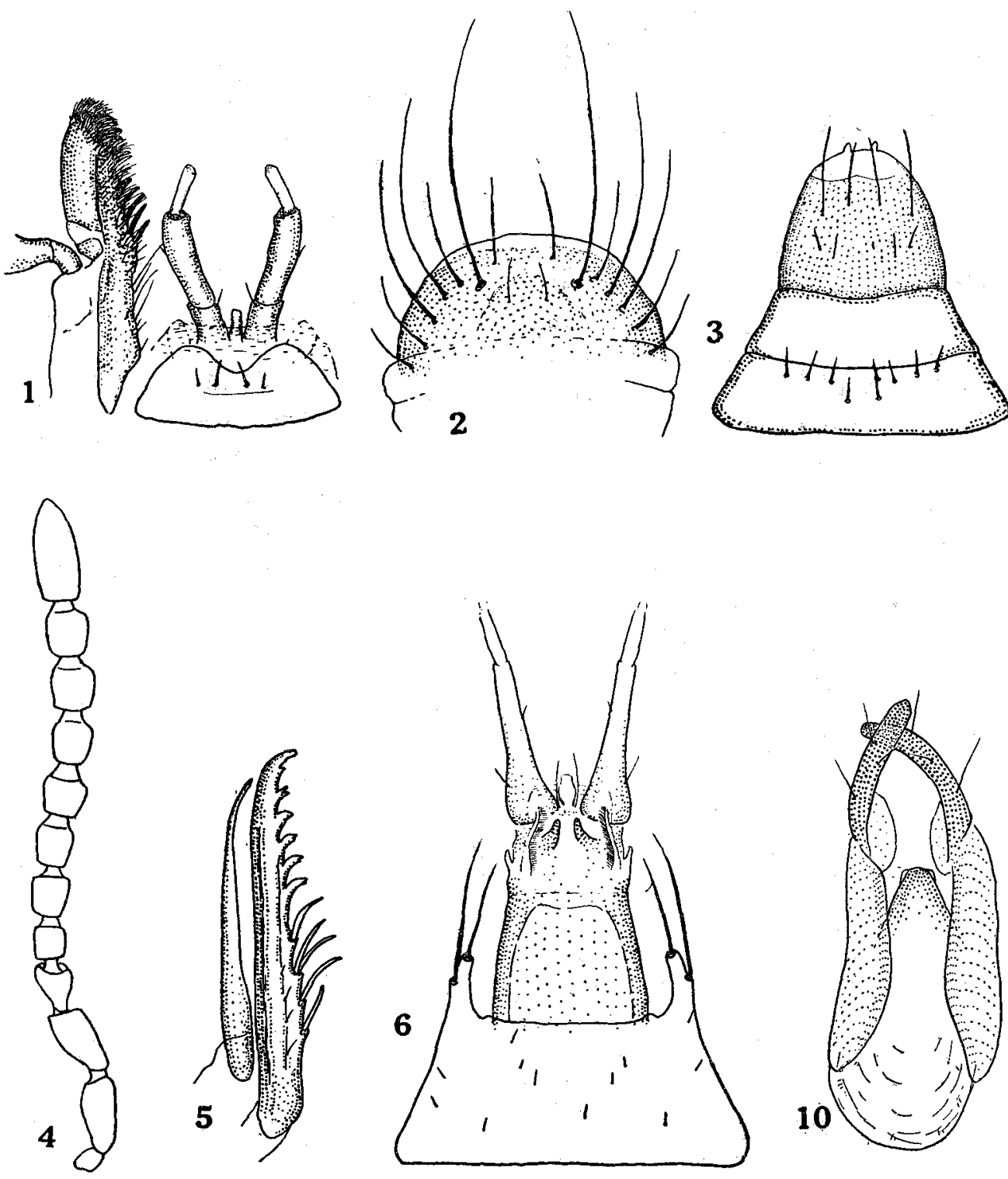

K. Sawada: Marine Insects of the Tokara Islands, VIII. 
Publ. Seto Mar. Biol. Lab., V, 1 (1955)

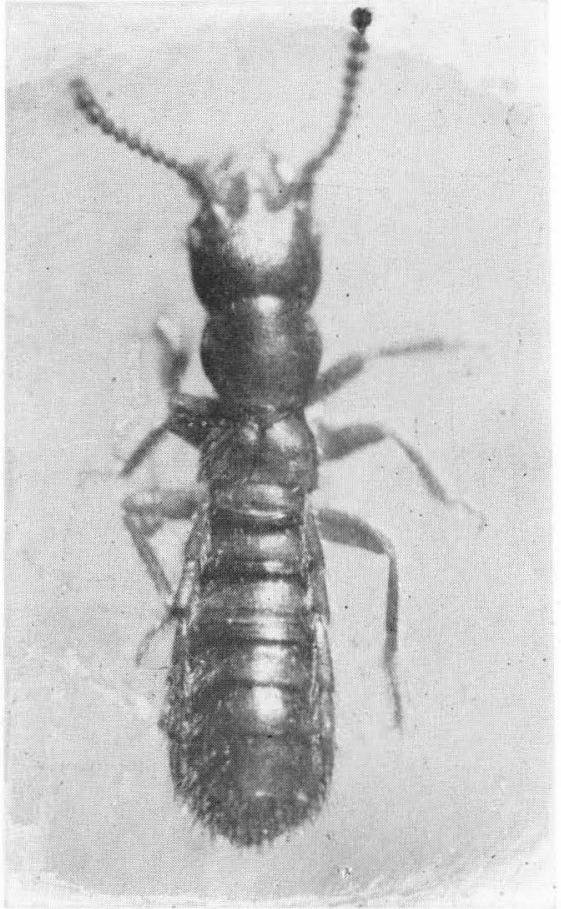

Genoplectes uenoi, g. nov., sp. nov.

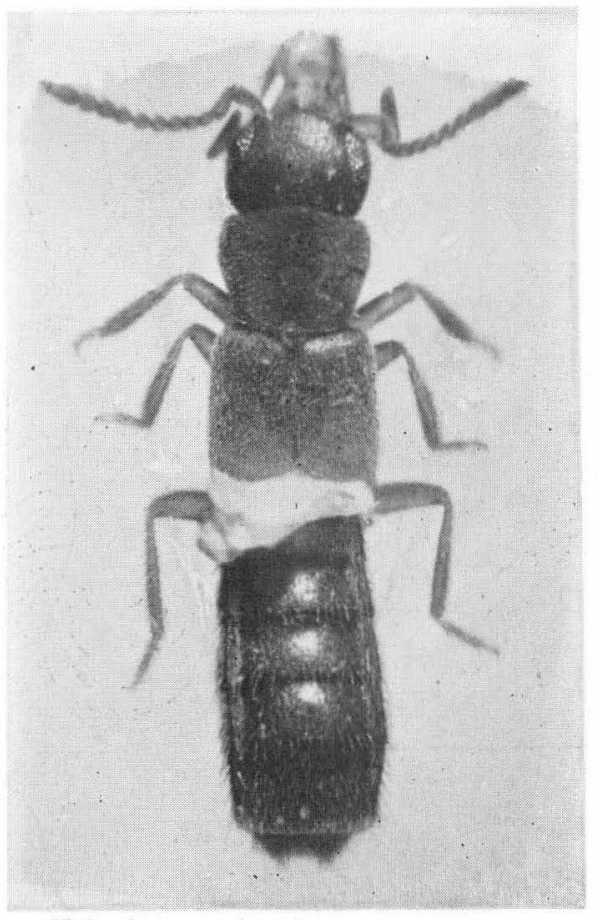

Halesthenus nakanei, g. nov., sp. nov.

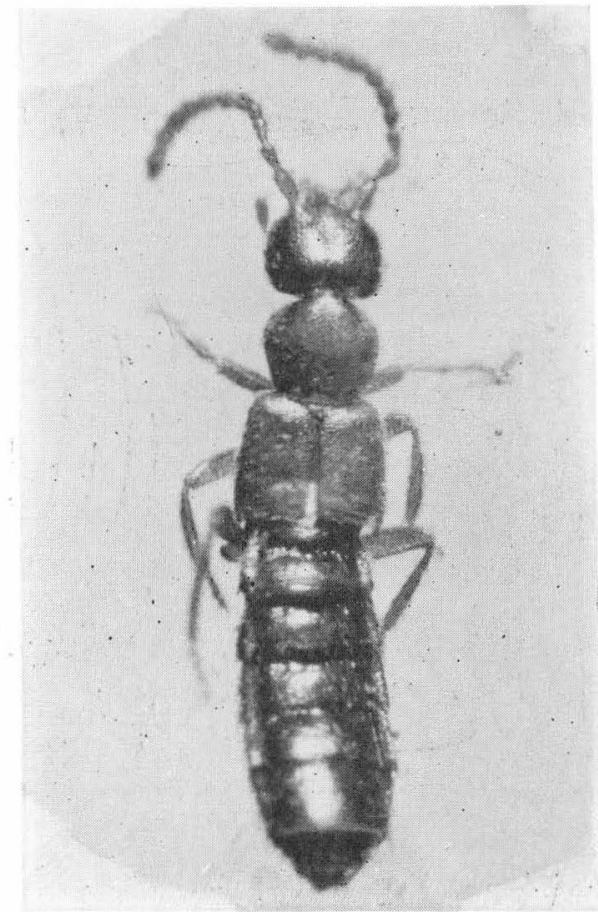

Ischnopoda (Stethusa) miyamotoi, sp. nov.
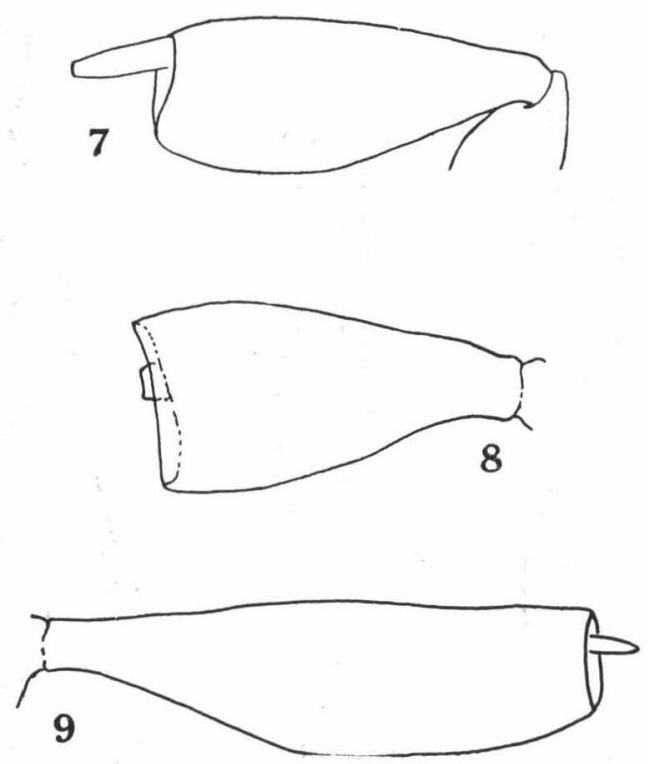

K. Sawada: Marine Insects of the Tokara Islands, VIII. 